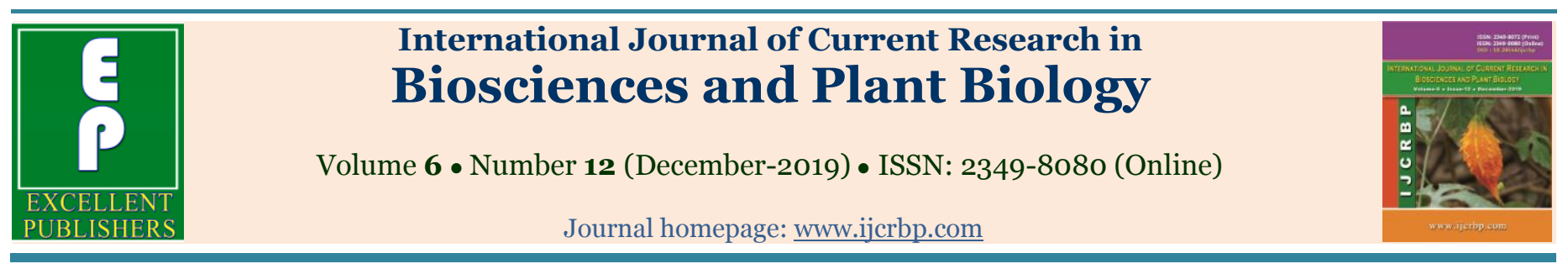

\title{
Alarming spread of invasive weeds: A qualitative assessment and scope for sustainable weed biomass utilization
}

\author{
R. Thangamani ${ }^{1, \#, ~ L . ~ B a s k a r a n ~}{ }^{1,2}$ and N. Karmegam ${ }^{1 *}$ \\ ${ }^{1}$ Department of Botany, Government Arts College (Autonomous), Salem-636 007, Tamil Nadu, India \\ ( Student, II year M.Sc., Botany) \\ ${ }^{2}$ Department of Botany, Annamalai University, Annamalai Nagar-608 002, Tamil Nadu, India \\ *Corresponding author; e-mail: kanishkarmegam@gmail.com
}

\begin{tabular}{ll}
\hline Article Info & ABSTRACT \\
\hline $\begin{array}{l}\text { Date of Acceptance: } \\
\text { 15 October 2019 }\end{array}$ & $\begin{array}{l}\text { The introduction of indigenous or exotic weeds to the habitats outside their native } \\
\text { range and their successful colonization is defined as biological invasion which } \\
\text { ultimately poses threat to economy, environment and biodiversity. In the present study, } \\
\text { the invasive plant species with special reference to the invasive plants in Salem District, } \\
\text { Date of Publication: } \\
\text { o6 December 2019 }\end{array}$ \\
$\begin{array}{ll}\text { Tamil Nadu, India and the possible threat to the local biodiversity by their invasion has } \\
\text { been investigated. The study focused the rapid spread of invasive weeds, } \\
\text { Keywords }\end{array}$ & $\begin{array}{l}\text { Alternanthera ficoidea (L.) P. Beauv., Alternanthera philoxeroides (Mart.) Griseb., } \\
\text { Chromolaena odorata (L.) R.M.King \& H.Rob., Ipomoea staphylina Roem. \& Schult., } \\
\text { Lantana camara L., Parthenium hysterophorus L. and Sesamum alatum Thonn. In } \\
\text { view of the biodiversity threat by these invasive weeds, possible utilization of weed- } \\
\text { biomass through vermicomposting is addressed. } \\
\text { Invasive weeds } \\
\text { Vermicomposting } \\
\text { Weed biomass }\end{array}$ \\
\hline
\end{tabular}

\section{Introduction}

Invasive alien weeds are given importance due to their impact on global economy, biodiversity and the environment. This scenario is mainly accompanied by the climate change which has implicated on the indigenous biodiversity shift (Disha et al., 2017). The alien weeds which has become naturalized successfully, spread, shift the native flora and cause threat to agriculture, ecosystem, and local resources are regarded as invasive weeds - the second largest root of biodiversity loss (Sudhakar Reddy et al., 2008). Early monitoring through qualitative and quantitative approaches is supposed to be helpful in the management of invasive weeds. However, the control measures are too expensive which requires continuous site-eradication, monitoring and follow-up programmes (Sudhakar Reddy et al., 2008). Among these, the collection of base-line data on the status, growth form and life cycle, and precise discrimination of invasive weeds with that of native species are to be given prime importance (Preston et al., 2004).

In India, a total of 173 species of invasive alien plant species belonging to 117 genera (44 families) were reported which accounts to one percent of the Indian flora (Sudhakar Reddy et al., 2008). A recent study conducted in Rourkela, Odhisa recorded a total of 165 invasive alien species belonging to 132 genera and 59 families (Narayan 
Mallick et al., 2019), indicating that the invasive alien weeds are rapidly spreading. According to Early et al. (2016), 1/6 $6^{\text {th }}$ of the land surface around the earth is highly vulnerable to invasion, including substantial areas in developing economies and biodiversity hotspots. For controlling the invasive weeds, mechanical, chemical and biological methods have been used where each method is having its own drawbacks and requires heavy investment (Sudhakar Reddy et al., 2008). As far as the biological control methods are concerned, utilization of weed biomass for compost and vermicompost preparation has been suggested (Negi et al., 2019; Saha et al., 2018). In the present qualitative study, major invasive alien weeds in Salem District, Tamil Nadu, India, their threat to biodiversity and ecosystem balance along with the possible role of vermicomposting in utilizing invasive weed biomass have been discussed.

\section{Methods}

By conducting regular field visits, qualitative assessment of invasive weed species has been documented during 2015-2019. The identification of invasive weeds was done using local floras. Based on the increase in number during subsequent years, the major invasive weeds of different habitats in Salem District, Tamil Nadu was recorded. The suggestion on the possible utilization of invasive weed biomass has been done as per the data available in the literature.

\section{Dominant invasive weeds}

The qualitative survey conducted on regular and seasonal basis during the study period (2015-2019) showed rapid invasion by a number of weeds in plains, cultivated lands, foothills, and in higher elevation of Shervaroyan hills. Among the invasive alien species, seven weeds were found to be dominant and spreading to new habitats: Alternanthera ficoidea (L.) P. Beauv. (Amaranthaceae, Fig. 1A), Alternanthera philoxeroides (Mart.) Griseb. (Amaranthaceae, Fig. 1B), Ipomoea staphylina Roem. \& Schult. (Convolvulaceae, Fig. 1C), Sesamum alatum Thonn. (Pedaliaceae, Fig. 1D), Chromolaena odorata (L.) R.M.King \& H.Rob. (Asteraceae, Fig. 1E), Lantana camara L. (Verbenaceae, Fig. 1F) and Parthenium hysterophorus L. (Asteraceae). Even though Parthenium hysterophorus seems to be widespread,
Alternanthera ficoidea is the faster invader in comparison, occupies the entire area within two seasons/a year of its first appearance due to the formation of enormous number of seeds produced per plant. Its overgrowth completely arrests the herbaceous native plants. Alternanthera ficoidea along with Alternanthera philoxeroides were observed to grow robust during rainy season especially in sewage open drainage pathways and invaded almost all parts of Salem city and urban areas of the district with minimum appearance in rural areas. Alternanthera philoxeroides was found throughout the year in ditches and open drainage pathways. The abundance of Alternanthera philoxeroides might be due to the maximum germination percentage of the seeds (96.6\%) (Patil and Kore, 2018), and high vegetative propagation rate. This weedy plant is used as green vegetable in some parts, and it contains useful nutrients, pehnolics and antioxidants. However, Alternanthera philoxeroides is known to accumulate heavy metals, hence poses health risks upon consumption (Suthari et al., 2017). In foothills and hill tracts of Shervaroys, Chromolaena odorata and Lantana camara were equally dominant, invaded most of the foothill areas which severely affected the herbaceous and shrubby vegetation. Whereas, Ipomoea staphylina-a robust seasonal climbing weed, entirely covers the underground vegetation including large trees (Fig. $1 \mathrm{E})$. In plains, especially roadsides and adjacent waste lands, and agricultural fields, Sesamum alatum was observed to be increasing at faster rates season by season. This invasive weed spreads quickly to new habitats including agricultural fields due to the possession of light weight winged seeds that can be dispersed easily through wind. To our knowledge, very little efforts have been taken to control the listed invasive alien weeds in Salem District, Tamil Nadu posing a high risk of shift of plant diversity. The monitoring of invasive weeds, dispersal mechanism and control measures are required to check the invasive weeds to natural habitats and agricultural lands. Otherwise, the large biomass of invasive weeds needs to be utilized properly according to the local requirements. For instance, obtaining natural cellulosic fibers from the stem of Ipomoea staphylina (Santhanam et al., 2016); Lantana camara sticks for making furnitures, artifacts and baskets (Negi et al., 2019); Lantana camara and Parthenium hysterophorus for vermicomposting (Devi and Khwairakpam, 2020a; Hussain et al., 2016a). 


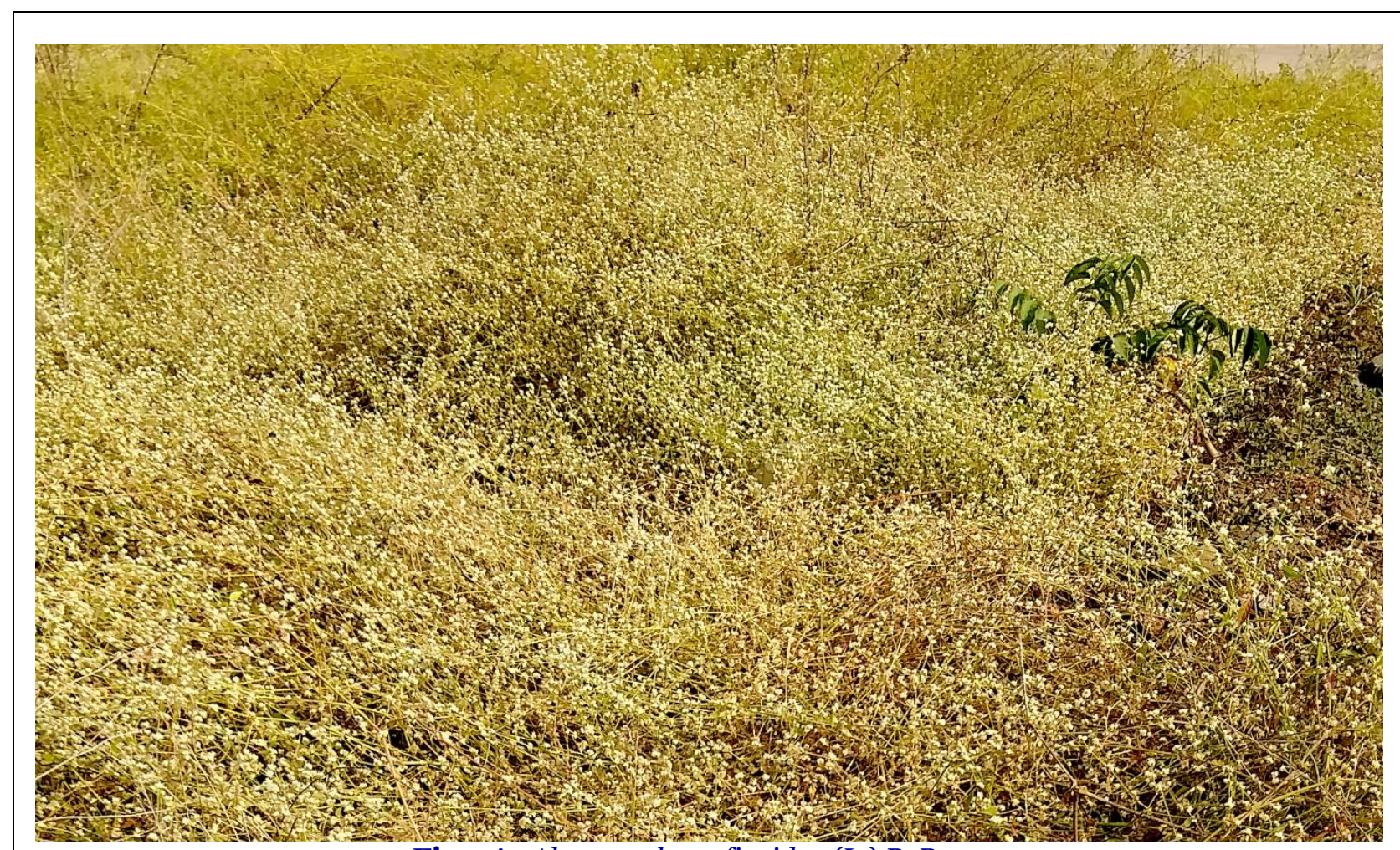

Fig. 1A: Alternanthera ficoidea (L.) P. Beauv.

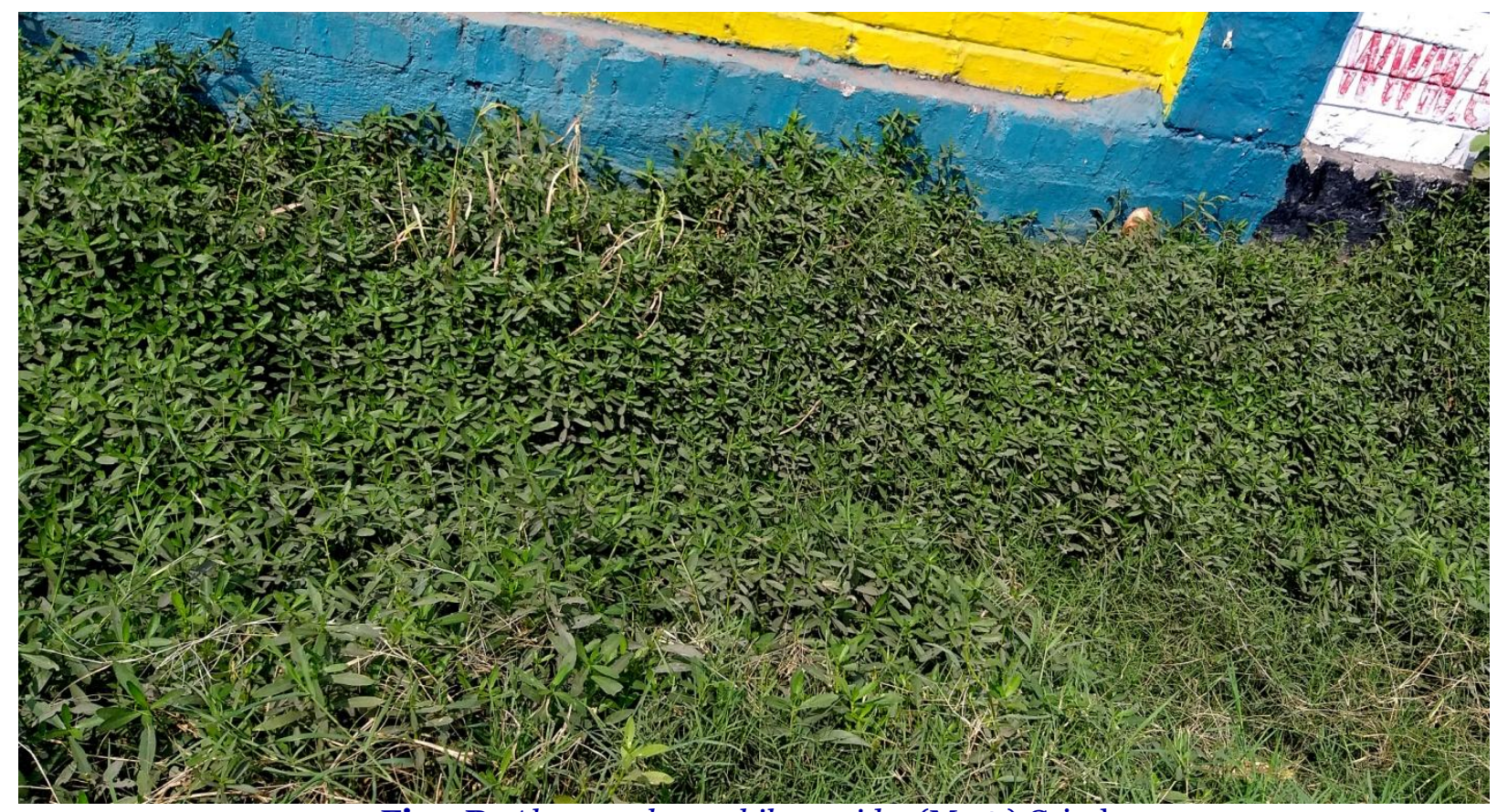

Fig. 1B: Alternanthera philoxeroides (Mart.) Griseb. 


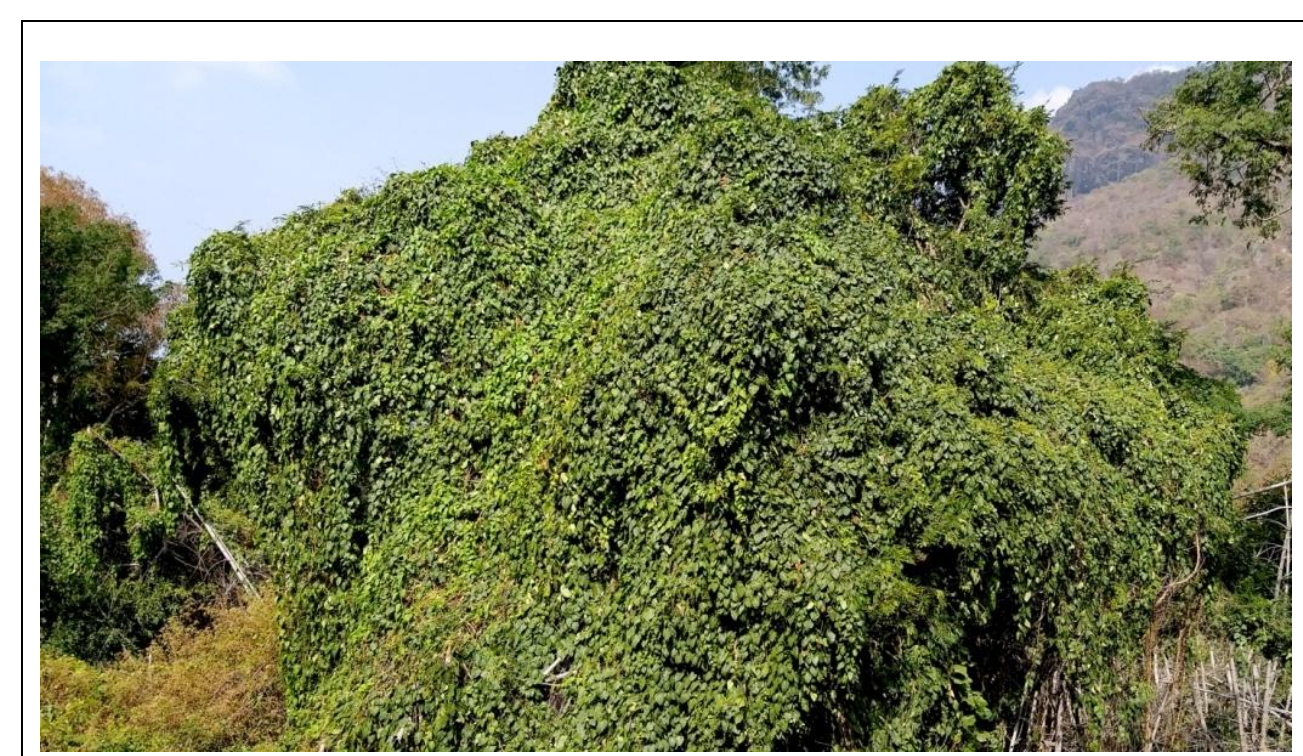

Fig. 1C: Ipomoea staphylina Roem. \& Schult.

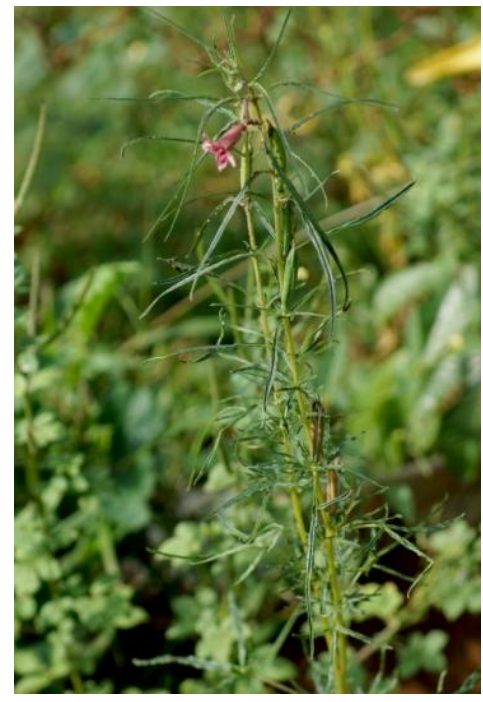

Fig. 1D: Sesamum alatum Thonn.

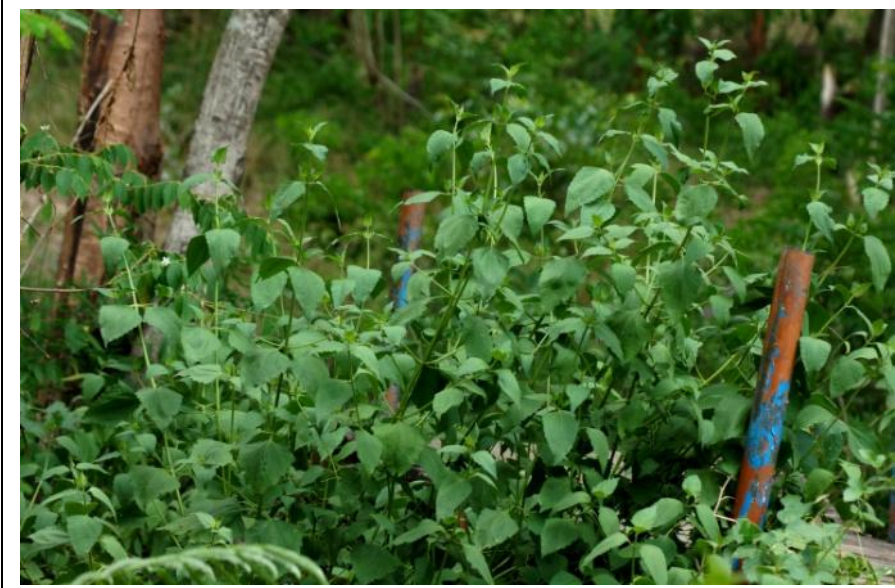

Fig. 1E: Chromolaena odorata (L.) R.M.King \& H.Rob.

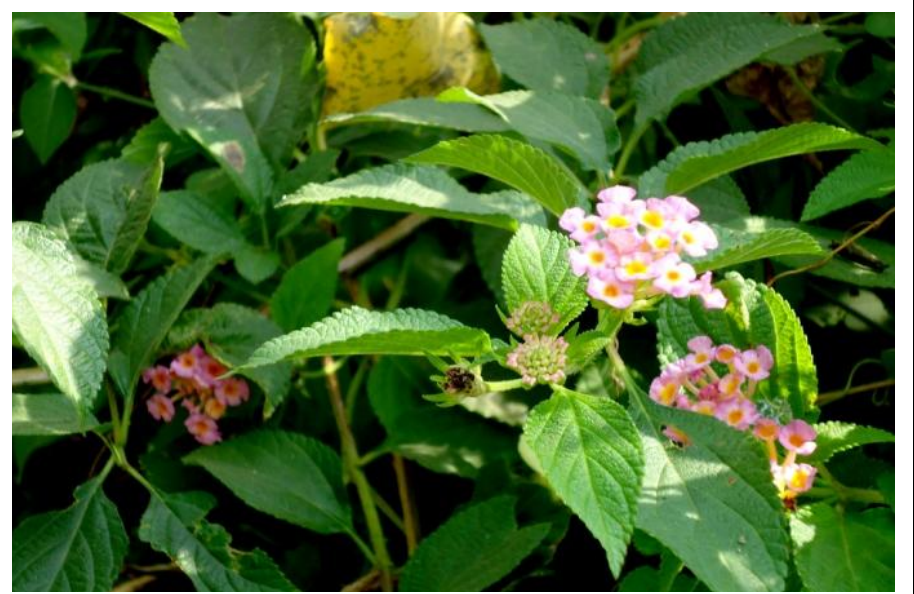

Fig. 1E: Lantana camara L.

Fig. 1: Dominant invasive alien weed species in Salem District, Tamil Nadu.

\section{Scope for sustainable management of weed biomass}

Apart from various mechanical, cultural, chemical and biological weed management strategies, vermicomposting is suggested for utilizing enormous invasive weed biomass for nutrient recovery and vermicompost production in a sustainable manner. The studies carried out for the management weed biomass through vermicomposting are provided in Table 1, for adoption in large scale. Other invasive weed biomass not listed in the table can also be tried for vermicomposting as a management strategy towards invasive alien weeds. Though the vermicomposting is an eco-friendly technology for organic waste / biomass conversion into valuable organic manure-the vermicompost, care should be taken to check the presence of viable seeds of invasive weeds. Readily, aerobic or anaerobic predecomposition is helpful to reduce the viability of seeds. Otherwise, there is a risk of dissemination of seeds of invasive weeds through vermicompost application. The literature provided in Table 1 clearly indicates that there is a vast scope for utilizing invasive weed biomass as feed-stocks for vermicomposting technology, which can be adopted / implemented easily at low cost. 
Table 1. Weed biomass as feed-stocks for vermicomposting technology.

\begin{tabular}{|c|c|c|c|}
\hline $\begin{array}{l}\text { Sl. } \\
\text { No. }\end{array}$ & Weed biomass used & $\begin{array}{l}\text { Earthworm species } \\
\text { employed }\end{array}$ & Reference \\
\hline 1. & Lantana camara & $\begin{array}{l}\text { Eisenia fetida and } \\
\text { Eudrilus eugeniae }\end{array}$ & Devi and Khwairakpam (2020a) \\
\hline 2. & Lantana camara & Eisenia fetida & Suthar and Sharma (2013) \\
\hline 3. & Lantana camara & Eisenia fetida & Hussain et al. (2016b) \\
\hline 4 . & Parthenium hysterophorus & Eudrilus eugeniae & Rajiv et al. (2013) \\
\hline 5 . & Ageratum conyzoides & Eisenia fetida & Devi and Khwairakpam (2020b) \\
\hline 6. & Parthenium hysterophorus & Eisenia fetida & Yadav and Garg (2011) \\
\hline 7. & Ipomoea carnea & Eisenia fetida & Hussain et al. (2016c) \\
\hline 8. & Salvinia molesta & Eisenia fetida & Hussain et al. (2016d) \\
\hline 9. & Eichhornia crassipes & Eisenia fetida & Singh and Kalamdhad (2013) \\
\hline 10. & Eichhornia crassipes & $\begin{array}{l}\text { Eudrilus eugeniae and } \\
\text { Perionyx excavatus }\end{array}$ & Varma et al. (2016) \\
\hline 11. & Seaweeds & Perionyx excavatus & Ananthavalli et al. (2019a, 2019b) \\
\hline
\end{tabular}

\section{Conflict of interest statement}

Authors declare that they have no conflict of interest.

\section{References}

Ananthavalli, R., Ramadas, V., John Paul, J.A., Karunai Selvi, B., Karmegam, N., 2019a. Seaweeds as bioresources for vermicompost production using the earthworm, Perionyx excavatus (Perrier). Bioresour. Technol. 275, 394-401.

Ananthavalli, R., Ramadas, V., John Paul, J.A., Karunai Selvi, B., Karmegam, N., 2019b. Vermistabilization of seaweeds using an indigenous earthworm species, Perionyx excavatus (Perrier). Ecol. Eng. 130, 23-31.

Devi, C., Khwairakpam, M., 2020a. Bioconversion of Lantana camara by vermicomposting with two different earthworm species in monoculture. Bioresour. Technol. 296, 122308.

Devi, C., Khwairakpam, M., 2020b. Feasibility of vermicomposting for the management of terrestrial weed Ageratum conyzoides using earthworm species Eisenia fetida. Environ. Technol. Innov. 18, 100696.

Disha, J., Mayank, V., Saurabh, P., Niraj, T., Meenal, R., Raghwendra, S., Bhumesh, K., 2017. Invasive alien weed species: a threat to plant biodiversity. In: Plant Biodiversity: Monitoring, Assessment and Conservation. CABI, pp. 564-592.

Early, R., Bradley, B.A., Dukes, J.S., Lawler, J.J., Olden, J.D., Blumenthal, D.M., Gonzalez, P.,
Grosholz, E.D., 2016. Global threats from invasive alien species in the twenty-first century and national response capacities. Nat. Commun. 7, 12485.

Hussain, N., Abbasi, T., Abbasi, S.A., 2016a. Vermicomposting transforms allelopathic Parthenium into a benign organic fertilizer. J. Environ. Manage. 180, 180-189.

Hussain, N., Abbasi, T., Abbasi, S.A., 2016 b. Transformation of toxic and allelopathic Lantana into a benign organic fertilizer through vermicomposting. Spectrochim. Acta Part A Mol. Biomol. Spectrosc. 163, 162-169.

Hussain, N., Abbasi, T., Abbasi, S.A., 2016c. Vermicomposting-mediated conversion of the toxic and allelopathic weed Ipomoea into a potent fertilizer. Process Saf. Environ. Prot. 103, 97-106.

Hussain, N., Abbasi, T., Abbasi, S.A., $2016 \mathrm{~d}$. Vermiremediation of an invasive and pernicious weed salvinia (Salvinia molesta). Ecol. Eng. 91, 432-440.

Narayan Mallick, S., Xenan Ekka, N., Kumar, S., C. Sahu, S., 2019. Invasive Alien Flora in and around an Urban Area of India. In: Diversity and Ecology of Invasive Plants. IntechOpen. https://doi.org/10.5772/intechopen.88725

Negi, G.C.S., Sharma, S., Vishvakarma, S.C.R., Samant, S.S., Maikhuri, R.K., Prasad, R.C., Palni, L.M.S., 2019. Ecology and use of Lantana camara in India. Bot. Rev. 85, 109-130.

Patil, R.B., Kore, B.A., 2018. Morphoanatomy , phenology and palynology of an invasive weed Alternanthera ficoidea (L.) P. Beauv. IOSR J. Pharm. Biol. Sci. (IOSR-JPBS 13, 18-23. 
Preston, C.D., Pearman, D.A., Hall, A.R., 2004. Archaeophytes in Britain. Bot. J. Linn. Soc. 145, 257-294.

Rajiv, P., Rajeshwari, S., Hiranmai Yadav, R., Rajendran, V., 2013. Vermiremediation: detoxification of parthenin toxin from Parthenium weeds. J. Hazard. Mater. 262, 489-495.

Saha, B., Devi, C., Khwairakpam, M., Kalamdhad, A.S., 2018. Vermicomposting and anaerobic digestion - viable alternative options for terrestrial weed management - A review. Biotechnol. Rep. 17, 70-76.

Santhanam, K., Kumaravel, A., Saravanakumar, S.S., Arthanarieswaran, V.P., 2016. Characterization of new natural cellulosic fiber from the Ipomoea staphylina plant. Int. J. Polym. Anal. Charact. 21, 267-274

Singh, J., Kalamdhad, A.S., 2013. Effect of Eisenia fetida on speciation of heavy metals during vermicomposting of water hyacinth. Ecol. Eng. 6o, 214-223.

Sudhakar Reddy, C., Bagyanarayana, G., Reddy,
K.N., Raju, V.S., 2008. Invasive alien flora of India, National Biological Information Infrastructure, US Geological Survey, USA http://www.gisinetwork.org.

Suthar, S., Sharma, P., 2013. Vermicomposting of toxic weed - Lantana camara biomass: Chemical and microbial properties changes and assessment of toxicity of end product using seed bioassay. Ecotoxicol. Environ. Saf. 95, 179-187.

Suthari, S., Kiran, B.R., Prasad, M.N.V., 2017. Health risks of leafy vegetable Alternanthera philoxeroides (Alligator weed) rich in phytochemicals and minerals. EuroBiotech J. 1, 293-302.

Varma, V.S., Kalamdhad, A.S., Khwairkpam, M., 2016. Feasibility of Eudrilus eugeniae and Perionyx excavatus in vermicomposting of water hyacinth. Ecol. Eng. 94, 127-135.

Yadav, A., Garg, V.K., 2011. Vermicomposting - An effective tool for the management of invasive weed Parthenium hysterophorus. Bioresour. Technol. 102, 5891-5895.

\section{How to cite this article:}

Thangamani, R., Baskaran, L., Karmegam, N., 2019. Alarming spread of invasive weeds: A qualitative assessment and scope for sustainable weed biomass utilization. Int. J. Curr. Res. Biosci. Plant Biol. 6(12), 20-25. doi: https://doi.org/10.20546/ijcrbp.2019.612.003 